\title{
Dr. Mohsen Ziai, the Internationally Renowned Professor of Universities in Iran and USA Passed Away
}

\author{
Mansour Bahrami ${ }^{1,}$ \\ ${ }^{1}$ Department of Pediatrics, Shahid Beheshti University of Medical Sciences, Tehran, IR Iran \\ *Corresponding author: Mansour Bahrami, Department of Pediatrics, Shahid Beheshti University of Medical Sciences, Tehran, IR Iran. Tel:+98-2122427972, E-mail: mansourbahrami@ \\ yahoo.com.
}

Received: September 28, 2013; Accepted: September 28, 2013

Keywords: Iran; Pediatrics

Iranian Society of Pediatrics expresses its most sincere condolences on the occasion of this sad event to his kind wife, dear children, relatives and the esteemed family of the late professor Dr. Mohammad Garib, friends, and the venerable society of Iranian Medicine. On the event of this occasion a brief biography of Dr. Mohsen Ziai, his fruitful life and valuable services is presented here:

Dr. Mohsen Ziai was born in Khorasan, the eighth generation of his family of doctors from Torbat-e-Heidarieh region. He was born in 1928 and passed away in April, 2013. He pursued his studies up to the end of high school in Torbat-e-Heidarieh, Mashhad and Tehran and went to Johns Hopkins University (Baltimore) for General Medicine courses.

Specialty and subspecialty education in infectious diseases: Harvard University

Books:

Four books in the field of pediatrics are his memorable works. These four books are:

1)Pediatrics Text Book

2)Bedside Pediatrics

3)Neonatal Medicine

4)The Joys of Pediatrics

In addition he published frequent essays in the field of health and hygiene and pediatrics training in famous, international medical journals.

Membership in global associations and awards/honors achieved during service in USA.

Honoury member of American Pediatric Society.

Member of Mother/Child Experts Committee in WHO.

Member of Pediatric Infection Disease Specialists.

Membership of Alpha Omega Alpha Medical Honor Society.

Honorary Fellow, American Academy of Pediatrics. Alumni Distinguished Achievement Award from Davis and Elkins College.

Outstanding Faculty Teaching Award by the Pediatric House Staff University of Rochester, 1979.

Third Year Outstanding Teacher Award, University of Rochester School of Medicine and Dentistry, 1981.

Keith Miner Ford Award for Excellence in Teaching by the Graduating Class of 1982, The University of Rochester School of Medicine and Dentistry.

Third Year Outstanding Teacher Award, The University of Rochester School of Medicine and Dentistry, Class of 1983.

Honored by Rochester General House-Staff 1982

Teacher of the Year Award by the Pediatric House Staff, Georgetown University, 1983.

Honored by Shiraz University Medical School Alumni Association 1989.

Golden Apple Award by the Georgetown University School of Medicine, presented in 1985, 1987, 1988, and 1994. Golden Apple Orchard, 1988 and in 1994 selected beyond the Orchard; all presented by Georgetown University Medical Students.

Teacher of the Year, Presented by Inova Fairfax Hospital for Children House-Staff, 1998, 2000.

Honored by Iranian American Medical Association, 1998.

Lifetime Achievement Award, Virginia Chapter, American Academy of Pediatrics, 2000.

Samuel P. Asper Award in International Medical Education Presented by Johns Hopkins University, June 2001.

Honorary Doctor of Science Degree/David \& Elkins Collage, 31 March 2003.

The late Dr. Mohsen Ziai, one of the genius figures of medicine in the world, provided exceptional and memorable services in Iran and USA.

Among his substantial services in pediatrics are empha- 
sis on primary health care, community pediatric, necessity of expanding ambulatory pediatrics and spreading the approach of global pediatric health care services. These issues are now considered by health care experts and policy makers.

He possessed a brilliant and exceptional mind and finished the four year college course in USA in only in two years. He started studying medicine in Johns Hopkins University immediately and graduated successfully. He completed his pediatric infections specialty and subspecialty in Harward University.

Dr. Mohsen Ziai returned to Iran when he was 29. Now, he was very knowledgeable and eager to serve his nation. He went back to Shiraz and through his strong connection with the faculties in Harward and Johns Hopkins Universities invited best professors in different fields of medicine to Shiraz University. Soon, Shiraz University was proud of having one of the strongest medical colleges in the world. After 6 years of service in Shiraz University he returned to USA and became a faculty member of Johns Hopkins University. During this period he recorded inventive and exceptional services. Drawing attention to ambulatory pediatrics, global pediatric health care and the importance of spreading preventive care are among the most significant issues.

In his second return to Iran, Dr. Mohsen Ziai (1960s) started working in Shiraz again. He made a lot of efforts to expand community pediatrics, provide health care and treatment services to remote areas, found training centers (primary to high school) working under Shiraz University and increase the scientific capabilities of Shiraz University. He was assigned as the Head of Mashhad University, Head of Tehran Medical Sciences University and Head of Medical Department before the Revolution respectively. In each of these positions he was a source of valuable services resulting in the promotion of medicine, especially pediatrics. During the last 9 years of his life and work in Tehran it was my privilege to be his student at first and colleague later. So I am going to mention some of his remarkable services during this period.

ShohadayeTajrish Hospital was a subsidiary of Sina Hospital until 1971. It was mainly an operation ward. When the late Dr. Mohsen Ziai was in charge this hospital became a training center and all medical specialties became active. Famous, eager and experienced professors directed different wards. Soon, this hospital became one of the advanced medical training centers of Iran. Because of the scientific connection with Johns Hopkins University the faculty members and other medical staff like students, interns and residents of all specialties were in touch and visited their peers in the other university.

The hospital achieved the highest scientific and training qualifications but community pediatrics and providing medical care were not neglected by Dr. Mohsen Ziai. Two efficient health services networks were established in Lorestan and Shemiranant from 1970 to 1977 to and were managed in the best way. At the same time Health Sciences College was being established, serious efforts were made to train effective medical care staff to offer primary health care to people all over the country. This college was active until 1978; Dr. Mohsen Ziai went to USA in 1977 and continued his scientific and training services at University of Rochester, New York, Georgetown University and John Hopkins University.

His latest feat in USA was turning the small pediatrics ward of Fairfax Hospital into a large pediatric center with 180 beds along with the maternity ward. It was a proof of the attitude that helping children is different from helping mothers. The name of the new ward changed to Inova Children Hospital. That was the reason Washington Post published the news of Dr. Mohsen Ziai's decease under an essay entitled "Mohsen Ziai Pediatrics Pathfinder" on April, 182013 and pointed out his exceptionally valuable services to children. Inova Hospital published a worthy essay on his decease, its scientific conference in 2013 will also be held in his name.

During his fruitful scientific life in US, the late Dr. Mohsen Ziai was a source of hope and help for Iranian doctors who decided to continue their studies in medicine in US as he was influential and highly respected for his knowledge. He helped everyone with no exceptions and his letters of introduction were accepted in all US universities. During his service time in US he achieved many acknowledgements and was elected as the best professor in the universities he worked. Years ago, in an extraordinary, unprecedented event Johns Hopkins University celebrated the 50th anniversary of his entry to their university.

Dr. Mohsen Ziai achieved such a level of fame and honor that most of renowned professors in pediatrics attended his retirement ceremony and Iranian doctors in US expressed their gratitude by sending worthy gifts to Fairfax Hospital, the last places he offered his services. In his last years, Dr. Mohsen Ziai was beside his kind, affectionate wife and wise, beloved children. He passed away in peace on March 27, 2103, at age 85.

In addition to his family and many friends, Pediatric Academy of America, Johns Hopkins University, Washington Post and Inova Children's Hospital also published death notices and mentioned his remarkable services to the pediatric society of the world expressing grief at his decease. They used very unique and proud phrases to describe him. The president of Johns Hopkins University wrote we are so proud to have presented such an outstanding figure to the world. In the memorial ceremonies what overwhelmed Dr. Mohsen Ziai's scientific privileges was a sense of his sublime ethical characteristics, patriotism, theology, generosity, open mindedness and his unforgettable, substantial services to the medical society of the world. He was a worthy man and his name will always shine in pediatrics. May he rest in peace. 


\section{Acknowledgements}

There are no acknowledgements.

\section{Financial Disclosure}

Author certifies that there is no conflict of interest with any financial organization.

\section{Funding Support}

There was no support for this research. 